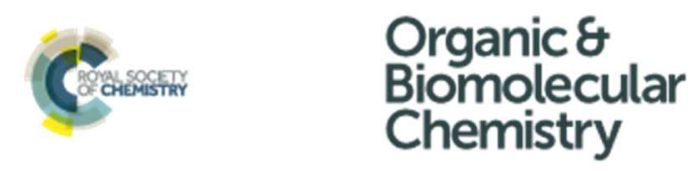

\title{
Carbonic anhydrase II as host protein for the creation of a biocompatible artificial metathesase
}

\begin{tabular}{|r|l|}
\hline Journal: & Organic \& Biomolecular Chemistry \\
\hline Manuscript ID: & OB-COM-03-2015-000428.R2 \\
\hline Article Type: & Paper \\
\hline Date Submitted by the Author: & O9-Apr-2015 \\
\hline Complete List of Authors: & $\begin{array}{l}\text { Zhao, Jingming; Department of Chemistry, University of Basel } \\
\text { Kajetanowicz, Anna; University of Basel, Department of Chemistry } \\
\text { Ward, Thomas; University of Basel, Department of Chemistry }\end{array}$ \\
\hline
\end{tabular}

\section{SCHOLARONE ${ }^{m}$




\section{Journal Name}

\section{ARTICLE}

\section{Carbonic anhydrase II as host protein for the creation of a biocompatible artificial metathesase}

Received 00th January 20xx, Accepted 00th January 20xx

DOI: $10.1039 / \times 0 \times x 00000 x$

www.rsc.org/

\author{
Jingming Zhao, Anna Kajetanowicz and Thomas R. Ward*
}

An artificial metathesase results from incorporation of an Hoveyda-Grubbs catalyst bearing an arylsulfonamide anchor within human carbonic anhydrase II. The optimization of the catalytic performance is achieved upon combining both chemical and genetic means. Up to 28 TONs were obtained within four hours under aerobic physiological conditions.
Artificial metalloenzymes result from the incorporation of an abiotic cofactor within a host protein. ${ }^{1}$ With biomedical applications in mind, it would be desirable to capitalize on a host protein which is overexpressed on the surface of cancer cells. Accumulation of the abiotic cofactor, which displays high affinity for the latter protein, may allow to site-specifically uncage a drug. ${ }^{2}$ In this context, the ring-closing metathesis (RCM) is an attractive reaction as unactivated diolefins can be viewed as bioorthogonal. Furthermore, the intramolecular nature of the RCM may facilitate the reaction under highly dilute aqueous conditions. ${ }^{3}$ Herein, we report on our efforts to exploit human Carbonic Anhydrase II (hCA II hereafter) for the creation of a biocompatible artificial metathesase, Scheme 1. Certain forms of cancer overexpress hCA IX, a membrane bound variant of hCA. These arylsulfonamide binding proteins are thus priviledged targets for cancer therapy. ${ }^{2,4 a}$
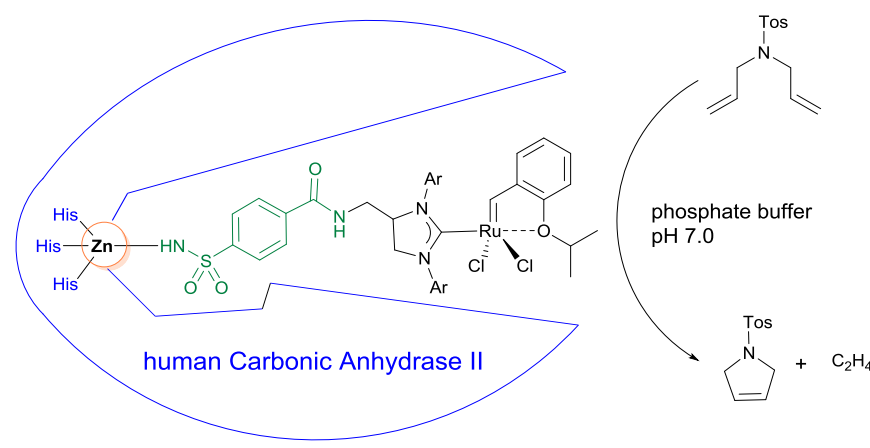

Scheme 1 Artificial metalloenzyme for ring-closing metathesis Tethering an arylsulfonamide anchor (green) to an Hoveyda-Grubbs type catalyst (black) ensures the localization of the metal moiety within human Carbonic Anhydrase II (blue).

Department of Chemistry, University of Basel, Spitalstrasse 51, CH-4056 Basel, Switzerland. E-mail: thomas.ward@unibas.ch

+ Electronic Supplementary Information (ESI) available: [details of any supplementary information available should be included here]. See DOI: $10.1039 / \mathrm{x} 0 \mathrm{xx} 00000 \mathrm{x}$
Introduction of an arylsulfonamide-anchor on an HoveydaGrubbs $2^{\text {nd }}$ generation-type catalyst ensures its localization within carbonic anhydrase. ${ }^{4}$ For this purpose, complexes Boc1, Boc-2 and Boc-3, ${ }^{5}$ were deprotected in situ and reacted with 4-sulfamoylbenzoic acid to afford the corresponding sulfonamide-bearing metathesis cofactors 1, 2 and 3, Scheme 2 (See SI for full experimental details).

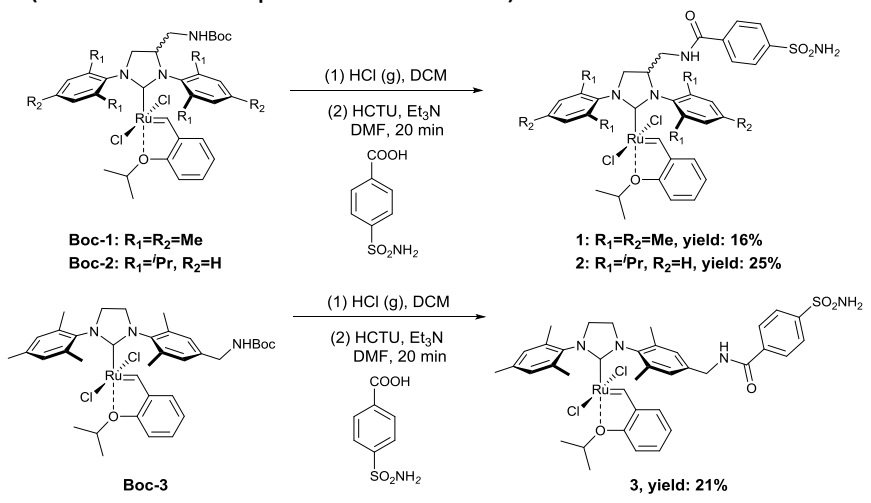

Scheme 2 Synthesis of olefin metathesase cofactors 1-3 bearing an arylsulfonamide anchor for incorporation within hCA II.

The catalytic performance of the artificial metathesases was evaluated using the ring-closing metathesis of $N$-tosyl diallylamine in the presence of $1 \mathrm{~mol} \%$ ruthenium. To ensure an homogeneous mixture, water/DMSO (9/1) was selected.

Comparison of catalysts 1-3 in the absence of hCA II at pH 6.0 in the presence of $0.1 \mathrm{M} \mathrm{MgCl}_{2}$ reveals that the bulkiest catalyst 2 outperforms catalysts 1 and 3 (Table 1, entries 1-3). The same trend is observed upon incorporation of the cofactors 1-3 into WT hCA II (Table 1, entries 4-6). Catalyst 2 was thus selected for further optimization. With no $\mathrm{MgCl}_{2}$ added and at $\mathrm{pH}$ 7.0, catalyst 2 and the corresponding metathesase $2 \subset$ WT hCA II afforded 23 and 14 turnovers after four hours at $37^{\circ} \mathrm{C}$. Performing catalysis under strict exclusion of oxygen yielded very similar results.

Reactions carried out at $\mathrm{pH} 7.0$ and in the presence of 154 $\mathrm{mM} \mathrm{NaCl}$ (corresponding to physiological conditions) yielded 32 and 21 TONs for $\mathbf{2}$ and $\mathbf{2} \subset$ WT hCA II respectively (Table 1, 
entries 15,16$)$. As can be appreciated, the TON of the catalyst is $\mathrm{pH}$ dependent, both in the presence and in the absence of hCA II. The best performance is obtained at lower $\mathrm{pH}$ and high salt concentration (Table 1, entries 12, 13). As for other artificial metalloenzymes, we do not believe that the $\mathrm{p} /$ of the host protein influences significantly the catalyst performance. ${ }^{6}$ Compared to the other four artificial metathesases reported to date, ${ }^{3 \mathrm{a}-3 \mathrm{e}}$ the system presented herein presents the following advantageous features (Table 2): i) it does not require an inert atmosphere; ii) the substrate concentration is the lowest of all systems reported to date; iii) except for the metathesase based on FhuA (which requires SDS, a surfactant), it displays the highest turnover frequency and iv) it catalyses $\mathrm{RCM}$ at $\mathrm{pH}$ 7.0, temperature $37{ }^{\circ} \mathrm{C}$ and physiological $[\mathrm{NaCl}]$ concentrations. These results thus suggest that WT hCA II is a suitable host for the creaction of artificial metathesases operating under physiological conditions and at low catalyst concentrations (i.e. $10 \mu \mathrm{M}$ ).

Table 1 Selected results for the ring-closing metathesis of $\mathrm{N}$-tosyl diallylamine. $^{a}$

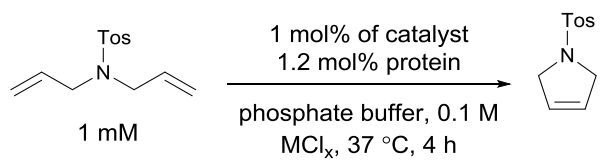

\begin{tabular}{|c|c|c|c|c|c|}
\hline Entry & Catalyst & hCA II & $\mathrm{pH}$ & {$\left[\mathrm{MCl}_{\mathrm{x}}\right] \mathrm{mol} / \mathrm{l}$} & TON $^{b}$ \\
\hline 1 & 1 & - & 6.0 & $\mathrm{MgCl}_{2} 0.1$ & $20 \pm 0.4$ \\
\hline 2 & 2 & - & 6.0 & $\mathrm{MgCl}_{2} 0.1$ & $48 \pm 0.8$ \\
\hline 3 & 3 & - & 6.0 & $\mathrm{MgCl}_{2} 0.1$ & $25 \pm 0.7$ \\
\hline 4 & 1 & WT & 6.0 & $\mathrm{MgCl}_{2} 0.1$ & $13 \pm 1.3$ \\
\hline 5 & 2 & WT & 6.0 & $\mathrm{MgCl}_{2} 0.1$ & $45 \pm 2.0$ \\
\hline 6 & 3 & WT & 6.0 & $\mathrm{MgCl}_{2} 0.1$ & $16 \pm 1.0$ \\
\hline 7 & 2 & WT & 6.0 & $\mathrm{NaCl} 0.2$ & $40 \pm 1.5$ \\
\hline 8 & 2 & WT & 7.0 & $\mathrm{NaCl} 0.2$ & $28 \pm 1.1$ \\
\hline 9 & 2 & - & 7.0 & - & $23 \pm 2.1$ \\
\hline 10 & 2 & WT & 7.0 & - & $14 \pm 0.5$ \\
\hline $11^{c}$ & 2 & WT & 7.0 & - & $20 \pm 2.3$ \\
\hline 12 & 2 & - & 5.0 & $\mathrm{MgCl}_{2} 0.5$ & $85 \pm 1.0$ \\
\hline 13 & 2 & WT & 5.0 & $\mathrm{MgCl}_{2} 0.5$ & $78 \pm 2.5$ \\
\hline 14 & 2 & WT & 6.0 & - & $23 \pm 2.6$ \\
\hline 15 & 2 & WT & 8.0 & - & $21 \pm 1.2$ \\
\hline 16 & 2 & - & 7.0 & $\mathrm{NaCl} 0.154$ & $32 \pm 2.0$ \\
\hline 17 & 2 & WT & 7.0 & $\mathrm{NaCl} 0.154$ & $21 \pm 1.8$ \\
\hline 18 & 2 & WT & 7.0 & $\mathrm{NaCl} 0.5$ & $32 \pm 1.8$ \\
\hline 19 & 2 & WT & 7.0 & $\mathrm{NaCl} 1.0$ & $29 \pm 1.2$ \\
\hline 20 & 2 & $191 \mathrm{~A}$ & 7.0 & - & $18 \pm 3.3$ \\
\hline 21 & 2 & F131A & 7.0 & - & $16 \pm 1.3$ \\
\hline 22 & 2 & L198F & 7.0 & - & $18 \pm 1.6$ \\
\hline 23 & 2 & L198H & 7.0 & - & $22 \pm 0.1$ \\
\hline 24 & 2 & L198H & 7.0 & $\mathrm{NaCl} 0.154$ & $28 \pm 0.6$ \\
\hline 25 & 2 & L198A & 7.0 & - & $15 \pm 1.7$ \\
\hline 26 & 2 & L198Q & 7.0 & - & $14 \pm 0.1$ \\
\hline 27 & 2 & K170A & 7.0 & - & $15 \pm 2.0$ \\
\hline \multicolumn{6}{|c|}{$\begin{array}{l}{ }^{\mathrm{a}} \text { Reaction conditions: [substrate] } 1 \mathrm{mM} \text {, [catalyst] } 10 \mu \mathrm{M} \text {, [hCA II] } 12 \mu \mathrm{M} \text {, } \\
\mathrm{V}_{\text {tot }} 200 \mu \mathrm{L}\left(\mathrm{V}_{\mathrm{DMso}} 20 \mu \mathrm{L}\right), 37^{\circ} \mathrm{C} \text { for } 4 \text { hours. The reactions were carried out } \\
\text { in triplicate. Very similar results were obtained under rigorous exclusion of } \\
\text { oxygen. }{ }^{b} \text { Turnover number. }{ }^{\mathrm{C}} \text { [substrate] } 5 \mathrm{mM} \text {, [catalyst] } 50 \mu \mathrm{M} \text {, [hCA II] } \\
60 \mu \mathrm{M} \text {. }\end{array}$} \\
\hline
\end{tabular}

To gain insight into the localization of rac-2 within WT hCA II, both enantiomers were docked using the GOLD program, Figure 1. As can be appreciated, the cofactor fits nicely within the cone-shaped binding funnel of hCA II, presenting its alkylidene moiety at the surface of the protein (Figure 1). With the aim of improving the TON of the artificial metathesase, residues 191, F131, L198, K170 were subjected to site-directed mutagenesis (Table 1, entries 20-27). Lypophylic, polar and potentially coordinating aminoacid residues were engineered into these positions. A selection of mutants tested is presented in Table 1, entries 20-27. To our delight, $\mathbf{2} \subset \mathrm{hCA}$ II L198H yielded significantly improved catalytic performance: up to 28 TONs under physiological conditions (Table 1, entry 24). Considering that both His198 and Phe198 affort similar TONs, we do not believe that the former residue coordinates to ruthenium. At this point however, it is difficult to rationalize or predict the effect a point mutations on the outcome of catalysis.

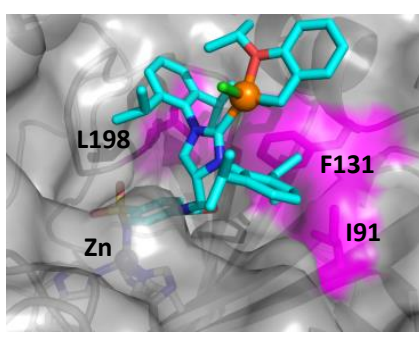

(a)

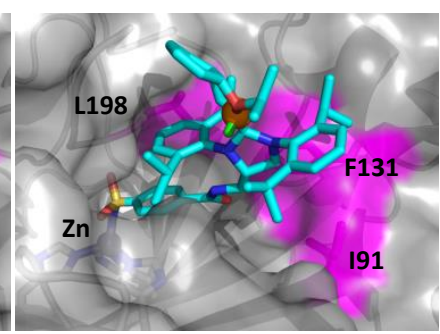

(b)
Fig. 1 Docked structure of $(R)-\mathbf{2} \subset$ WT hCA II (a) and (S)-2 $\subset$ WT hCA II (b). The ruthenium cofactor is displayed as stick and hCA II as solvent accessible transparent surface. Residues subjected to mutagenesis are highlighted in magenta.

In order to ensure localisation of the cofactor $\mathbf{2}$ within hCA II under catalytic conditions, its affinity was determined using the dansylamide displacement assay. ${ }^{8}$ Dansylamide (DNSA) displays enhanced fluorescence upon incorporation within hCA II. The non-covalent probe can be displaced by high affinity arylsulfonamide-bearing hCA II inhibitors, leading to a decrease in fluorescence.

For DNSA, we obtained a $K_{\mathrm{d}}=4.83 \mu \mathrm{M}$ and $17.35 \mu \mathrm{M}$ for WT hCA II and L198H hCA II respectively. The displacement assay (See SI for details) yielded $K_{\mathrm{d}}=90.40 \mathrm{nM}$ and $205.10 \mathrm{nM}$ for 2 $\subset$ WT hCA II and $\mathbf{2} \subset$ hCA II L198H respectively, Figure 2 . Although we cannot exclude additional non-specific binding on the surface of hCA II, we feel that the exquisite specificity of arylsulfonamides most probably ensures selective binding to the $\mathrm{Zn}(\mathrm{His})_{3}$ moiety. We tentatively attribute the modest quality of the fit to the use of a rac-2 (and thus the presence of two inhibitors with potentially different affinities). Under catalytic conditions $96 \%$ and $93 \%$ of $\mathbf{2}$ is bound to WT hCA II and hCA II L198H respectively. 
Table 2 Summary of the catalytic performance of artificial metathesases reported to date

\begin{tabular}{|c|c|c|c|c|c|}
\hline & Hilvert $^{3 b}$ & Ward $^{3 a}$ & Schwaneberg $^{3 d, 3 e}$ & Matsuo $^{3 c}$ & Ward \\
\hline [substrate] & $\underbrace{\text { Tos }}_{5 \mathrm{mM}}$ & $\underbrace{\text { Tos }}_{15.21 \mathrm{mM}}$ & $100 \mathrm{mM}$ & $8 \mathrm{mM}$ & $1 \mathrm{mM}$ \\
\hline $\begin{array}{l}\text { Reaction } \\
\text { type }\end{array}$ & $\mathrm{RCM}$ & $\mathrm{RCM}$ & ROMP & $\mathrm{RCM}$ & $\mathrm{RCM}$ \\
\hline $\begin{array}{l}\text { Anchoring of } \\
\text { Ru-cofactor }\end{array}$ & covalent & supramolecular & covalent & covalent & dative \\
\hline Host protein & $\begin{array}{l}\mathrm{MjHSP}^{[1]} \\
4 \mathrm{~mol} \%\end{array}$ & $\begin{array}{l}\text { Avidin } \\
4.8 \text { mol\% }\end{array}$ & $\begin{array}{c}\text { FhuA } \triangle D_{C V F}{ }^{\operatorname{tev}[2]} \\
0.08 \mathrm{~mol} \%\end{array}$ & $\begin{array}{c}\alpha \text {-Chymotrypsin } \\
0.63 \text { mol\% }\end{array}$ & $\begin{array}{l}\text { hCA II } \\
1 \mathrm{~mol} \%\end{array}$ \\
\hline $\begin{array}{c}\text { Temp. Time } \\
\text { pH }\end{array}$ & $\begin{array}{c}45^{\circ} \mathrm{C} \\
12 \mathrm{~h} \\
2\end{array}$ & $\begin{array}{c}40{ }^{\circ} \mathrm{C} \\
16 \mathrm{~h} \\
4\end{array}$ & $\begin{array}{c}25^{\circ} \mathrm{C} \\
68 \mathrm{~h} \\
7\end{array}$ & $\begin{array}{c}25^{\circ} \mathrm{C} \\
2 \mathrm{~h} \\
7\end{array}$ & $\begin{array}{c}37{ }^{\circ} \mathrm{C} \\
4 \mathrm{~h} \\
7\end{array}$ \\
\hline $\begin{array}{l}\text { Reaction } \\
\text { conditions }\end{array}$ & $\begin{array}{c}10 \mathrm{mM} \mathrm{HCl}, \\
\text { Water/t}-\mathrm{BuOH} \\
4 / 1 \\
\text { under air }\end{array}$ & $\begin{array}{c}0.1 \mathrm{M} \text { acetate } \\
\text { Water/DMSO } \\
5 / 1 \\
0.5 \mathrm{M} \mathrm{MgCl}_{2}, \\
\text { under air }\end{array}$ & $\begin{array}{c}\text { Water/THF } \\
9 / 1 \\
\text { SDS } 1 \% \\
\text { under } \mathrm{N}_{2}\end{array}$ & $\begin{array}{c}\text { Degassed } \\
100 \mathrm{mM} \mathrm{KCl} \text {, } \\
\text { under } \mathrm{N}_{2}\end{array}$ & $\begin{array}{c}0.1 \text { M phosphate } \\
\text { Water/DMSO } \\
9 / 1 \\
\text { under air }\end{array}$ \\
\hline TON & 25 & 20 & 955 & 20 & 28 \\
\hline \multicolumn{6}{|c|}{$\begin{array}{l}\text { [1] MjHSP: M. jannaschii small heat shock protein. } \\
\text { [2] GH-FhuA } \triangle D C V F^{\text {tev }} \text { : engineered variants of the } \beta \text {-barrel ferric hydroxamate uptake protein component } A\end{array}$} \\
\hline
\end{tabular}

(a) WT

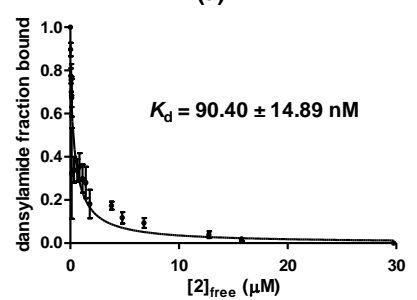

Fig. $\mathbf{2}$ Determination of the dissociation constant of $\mathbf{2} \subset \mathrm{hCA}$ II using the dansylamide displacement assay: WT hCA II (a) and L198H hCA II (b) [hCA II] $=0.25 \mu \mathrm{M}$, [Dansylamide] $=20 \mu \mathrm{M}$, See SI for full experimental details. All measurements were performed in duplicate.

\section{Conclusions}

In summary, we have developed an artificial metathesase relying on hCA II as host protein. Importantly, the present system operates under aerobic physiological conditions and at low catalyst concentrations (i.e. $10 \mu \mathrm{M}$ ). Current efforts are directed at evaluating hCA IX, a cell-surface hCA variant which is overexpressed in various forms of cancer.

\section{Experimental section}

Typical procedure for the ring closing metathesis

The following stock solutions were prepared: catalyst 2 (200 $\mu \mathrm{M})$ in DMSO, $N$-tosyldiallylamine $(20 \mathrm{mM})$ in DMSO and hCA II isoform solution $(13.3 \mu \mathrm{M})$ in phosphate buffer $(0.1 \mathrm{M}, \mathrm{pH}$ 7.0).

To a small glass vial, the catalyst $\mathbf{2}$ stock solution $(10 \mu \mathrm{L})$ was added to the protein stock solution $(180 \mu \mathrm{L})$. The mixture was incubated at $37{ }^{\circ} \mathrm{C}$ for $20 \mathrm{~min}$. The $\mathrm{N}$-tosyldiallylamine stock solution $(10 \mu \mathrm{L})$ was added and the reaction vial was placed in the incubator $\left(37^{\circ} \mathrm{C}\right)$ for $4 \mathrm{~h}$ at $200 \mathrm{rpm}$.

After completion of the reaction, 2-phenylethanol $(100 \mu \mathrm{L}$, used as internal standard, $1 \mathrm{mM}$ in $\mathrm{H}_{2} \mathrm{O}$ ) and $\mathrm{MeOH}(700 \mu \mathrm{L})$ were added. The mixture was transferred to an eppendorf tube and centrifuged at $14^{\prime} 000 \mathrm{rpm}$ for 15 minutes to precipitate hCA II. The supernatant $(500 \mu \mathrm{L})$ was transferred in an HPLC vial and water $(500 \mu \mathrm{L})$ was added. The sample was then subjected to reversed phase HPLC for TON analysis.

\section{Acknowledgements}

Financial support for this project was provided by the seventh framework programme project METACODE (KBBE, "Codeengineered new-to nature microbial cell factories for novel and safety enhanced bioproduction") and the Swiss National Science Foundation NCCR molecular systems engineering. JZ thanks the Chinese Scholarship Council. We thank C. Fierke (Univ. Michigan) for the hCA II plasmid. We thank Dr V. Köhler 
for his help with the 2D NMR characterization and Mr M. Barnet for his help with the docking simulation.

\section{Notes and references}

1 (a) F. Yu, V. M. Cangelosi, M. L. Zastrow, M. Tegoni, J. S. Plegaria, A. G. Tebo, C. S. Mocny, L. Ruckthong, H. Qayyum and V. L. Pecoraro, Chem. Rev., 2014, 114, 3495; (b) J. C. Lewis, ACS Catal., 2013, 3, 2954; (c) A. Ilie and M. T. Reetz, Isr. J. Chem., 2014, 55, 51; (d) M. Dürrenberger and T. R. Ward, Curr Opin Chem Biol, 2014, 19, 99; (e) A. J. Boersma, R. P. Megens, B. L. Feringa and G. Roelfes, Chem. Soc. Rev., 2010, 39, 2083; (f) Y. Lu, N. Yeung, N.Sieracki and N. M. Marshall, Nature, 2009, 460, 855; $(g)$ P. J. Deuss, R. den Heeten, W. Laan and P. C. Kamer, Chem. Eur. J., 2011, 17, 4680.

2 N. Krall, F. Pretto,W. Decurtins, G. J. L. Bernardes, C. T. Supuran and D. Neri, Angew. Chem., Int. Ed., 2014, 53, 4231.

3 (a) C. Lo, M. R. Ringenberg, D. Gnandt, Y. Wilson and T. R. Ward, Chem. Commun., 2011, 47, 12065; (b) C. Mayer, D. G. Gillingham, T. R. Ward and D. Hilvert, Chem. Commun., 2011, 47, 12068; (c) T. Matsuo, C. Imai, T. Yoshida, T. Saito, T. Hayashi and Shun Hirota, Chem. Commun., 2012, 48, 1662; (d) D. F. Sauer, M. Bocola, C. Broglia, M. Arlt, L. Zhu, M. Brocker, U. Schwaneberg and J. Okuda, Chem. Asian J., 2015 10, 177; (e) F. Philippart, M. Arlt, S. Gotzen, S. J. Tenne, M. Bocola, H. H. Chen, L. Zhu, U. Schwaneberg and J. Okuda, Chem. Eur. J., 2013, 19, 13865; (f) D. Burtscher and K. Grela, Angew. Chem. Int. Ed. 2009, 48, 442; (f) Y. Lin, J. M. Chalker and B. G. Davis, ChemBioChem, 2009, 10, 959.

4 (a) V. M. Krishnamurthy, G. K. Kaufman, A. R. Urbach, I. Gitlin, K. L. Gudiksen, D. B. Weibel and G. M. Whitesides, Chem. Rev., 2008, 108, 946; (b) F. W. Monnard, E. S. Nogueira, T. Heinisch, T. Schirmer and T. R. Ward, Chem. Sci., 2013, 4, 3269; (c) M. Schmid, E. S. Nogueira, F. W. Monnard, T. R. Ward and M. Meuwly, Chem. Sci., 2012, 3, 690; (d) F. W. Monnard, T. Heinisch, E. S. Nogueira, T. Schirmer and T. R. Ward, Chem. Commun., 2011, 47, 8238; (e) D. Can, B Spingler, P. Schmutz, F. Mendes, P. Raposinho, C. Fernandes, F. Carta, A. Innocenti, I. Santos, C. T. Supuran and R. Alberto, Angew. Chem. Int. Ed., 2012, 51, 3354.

5 (a) J. P. Jordan and R. H. Grubbs, Angew. Chem. Int. Ed., 2007, 46, 5152; (b) A. Kajetanowicz, A, Chatterjee, R, Reuter and T. R. Ward, Catal. Lett., 2014, 144, 373.

6 T. R. Ward, Acc. Chem. Res., 2011, 44, 47.

7 V. M. Robles, M. Dürrenberger, T. Heinisch, A. Lledós, T. Schirmer, T. R. Ward and J. D. Maréchal, J. Am. Chem. Soc., 2014, 136, 15676.

8 (a) S. C. Wang and D. B. Zamble, Biochem. Mol. Biol. Educ., 2006, 34, 364. (b) A. L. Banerjee, M. Swanson, B. C. Roy, X. Jia, M. K. Haldar, S. Mallik and D. K. Srivastava, J. Am. Chem. Soc., 2004, 126, 10875. 